\title{
A vetésváltás és az NPK tápanyagellátás hatása a kukorica termésére
}

\author{
SÁRVÁRI MIHÁLY-BOROS BEÁTA \\ Debreceni Egyetem AGTC, Növénytudományi Intézet, Debrecen
}

\section{Összefoglalás}

Tartamkísérletben, réti talajon vizsgáltuk a vetésváltás és az NPK mútrágyázás hatását a kukorica termésére.

A vetésváltás nagymértékben meghatározta a kukorica termése mellett az NPK mútrágya agroökológiai optimumát is. Kedvező vetésváltásban, trikultúrában (borsó - ôszi búza - kukorica - kukorica) 20 év átlagában 1,58 t/ha-ral, bikultúrában (őszi búza - kukorica - kukorica - ószi búza) 1,25 t/ha-ral nagyobb termést kaptunk a monokultúrában termesztett kukoricához viszonyítva.

A vetésváltás a kukorica termésstabilitását is nagymértékben befolyásolta. Kedvezô és kedvezótlen években egyaránt trikultúrában a legstabilabb a kukorica termése, ugyanakkor a környezeti feltételek javulásával szintén a trikultúrás kukorica képes a legnagyobb - akár 18 t/ha-os - terméseredményre. A vetésforgó és a N mútrágyázás jelentôs mértékben befolyásolta a talaj pH értékét, míg monokultúrás termesztés esetén szignifikánsan kisebb pH értéket kaptunk, mint bi-, illetve trikultúrás termesztés esetén.

A kukoricahibridek termóképessége, természetes tápanyagfeltáró- és hasznosító képessége, továbbá trágyareakciója is nagymértékben eltérő.

A kukoricahibrideket a termőképesség és a mútrágyareakció alapján intenzív, átlagos és extenzív csoportokba soroltuk.

Az agroökológiai mútrágyaoptimum előveteménytôl, évjárattól és a hibridtôl függóen $\mathrm{N} 40-120, \mathrm{P}_{2} \mathrm{O}_{5}$ 25-75, $\mathrm{K}_{2} \mathrm{O} 30-90 \mathrm{~kg} /$ ha hatóanyag, amellyel adott körülmények között a legnagyobb termést lehet elérni.

Kulcsszavak: vetésváltás, kukoricahibrid, mútrágyázás, termésstabilitás 


\title{
The effect of crop rotation and NPK fertilisation on maize yield
}

\author{
M. SÁRVÁRI-B. BOROS \\ University of Debrecen, Centre for Agricultural and Applied Economic Sciences, \\ Institute of Crop Sciences, Debrecen
}

\begin{abstract}
Summary
We examined the effect of crop rotation and NPK fertilisation on maize yield in a long-term experiment on meadow soil.

Crop rotation greatly determined both maize yield and the agroecologically optimal quantity of NPK fertilisers. Averaged over 20 years, maize yield increased by $1.58 \mathrm{t} \mathrm{ha}^{-1}$ in triculture and in a favourable crop rotation (pea - winter wheat - maize - maize), whereas this increment was $1.25 \mathrm{t} \mathrm{ha}^{-1}$ in biculture in comparison with maize produced in monoculture.

Crop production also largely influenced the yield stability of maize. Maize yield is the most stable is triculture both in favourable and unfavourable years, whereas the highest yield (even $18 \mathrm{t} \mathrm{ha}^{-1}$ ) under improved environmental conditions was also obtained in maize produced in triculture. Crop production and $\mathrm{N}$ fertilisation significantly affected soil $\mathrm{pH}$, whereas we obtained a significantly lower $\mathrm{pH}$ value in the case of monoculture in comparison with bi- and triculture.

The yield potential, natural nutrient utilisation ability and fertiliser reaction of maize hybrids greatly differ from each other.

Based on their yield potential and fertiliser reaction, we classified maize hybrids into intensive, average and extensive groups.

Depending on the previous crop, crop yeart and hybrid, the agroecologically optimal fertiliser dose was $\mathrm{N} 40-120, \mathrm{P}_{2} \mathrm{O}_{5} 25-75, \mathrm{~K}_{2} \mathrm{O} 30-90 \mathrm{~kg} \mathrm{ha}^{-1}$. This rate of active ingredients provides the highest yield under the given conditions.
\end{abstract}

Key words: crop rotation, maize hybrid, fertilisation, yield stability 


\section{Bevezetés}

A kukorica a jövő́ben stratégiai növény lesz a világon és Magyarországon is. Az eddigi elsôsorban élelmiszer és takarmány célú felhasználása mellett jelentôs mértékben nôni fog az ipari felhasználása (ipari cukor, bioetanol, stb.).

A kukorica vetésterülete a világon az utóbbi másfél évtizedben 25 millió hektárral nôttt, a hektáronkénti termésátlaga pedig 3,79 t/ha-ról 5,11 t/ha-ra növekedett, az összes termés 800 millió tonna felett van. A jelentôs vetésterület növekedés a fosszilis energiát bizonyos mértékig helyettesítô bioetanol gyártással hozható összefüggésbe.

A kukorica termésátlagát alapul véve Magyarország a világ rangsorában az 5 . helyet foglalja el (1. táblázat).

1. táblázat. A világ élvonala a kukoricatermesztésben termésátlag alapján, 1 millió ha feletti területtel rendelkezö országok adatai szerint (FAO adatok, 2008)

\begin{tabular}{lccc}
\hline \multicolumn{1}{c}{ Ország } & $\begin{array}{c}\text { Vetésterület } \\
(\text { ezer ha) }\end{array}$ & $\begin{array}{c}\text { Termésátlag } \\
(\mathrm{t} / \mathrm{ha}) \\
(2)\end{array}$ & $\begin{array}{c}\text { Összes termés } \\
\text { (millió tonna) } \\
(4)\end{array}$ \\
\hline 1. USA (5) & 31826 & 9,65 & 307,38 \\
2. Franciaország (6) & 1702 & 9,29 & 15,82 \\
3. Kanada (7) & 1168 & 9,06 & 10,59 \\
4. Olaszország (8) & 1053 & 9,01 & 9,49 \\
5. Magyarország (9) & 1199 & 7,17 & 8,96 \\
\hline
\end{tabular}

Table 1 . The main maize producer countries of the World ranked by average yield, sowing areas above 1 million ha (FAO data, 2008). (1) County, (2) Sowing area (thousand ha), (3) Average yield ( $\mathrm{t} \mathrm{ha}^{-1}$ ), (4) Total yield (million tons), (5) USA, (6) France, (7) Canada, (8) Italy, (9) Hungary.

Nagyon kedvezótlen azonban, hogy Magyarországon a hektáronkénti termésátlag ingadozás az 50-60\%-ot is eléri. Ennek oka részben a klímaváltozás, részben pedig az agrotechnikai múveletek terén tapasztalható hiányosságok. Az agrotechnikai tényezôk közül is a vetésváltás és tápanyagellátás az a két tényezô, amely jelentôs hatással van a termésmennyisége mellett a termésbiztonságra is. A megfelelố vetésváltás kialakítása hazánk kontinentális, szárazságra 
hajló éghajlata miatt is fontos. Az elővetemény, továbbá a gyomosodás mértékére, a kórokozók és a kártevốk elszaporodására egyértelmúen nagy hatást gyakorol (Berzsenyi 1995, Menyhért et al. 1980). Ezen tényezők közül különösen veszélyessé vált az amerikai kukoricabogár és lárvájának lehetséges kártétele (Kissné 2000, Széll és Makhajda 2003, Sárvári 2004). A monokultúrás termesztés nagy hátránya az amerikai kukoricabogár lárvakártétele mellett, hogy nem teszi lehetôvé a többi növény okszerú vetésváltását, a kedvezô elôvetemény-hatás érvényesülését (Kismányoki 1994).

A kukorica termését nagymértékben befolyásolja az NPK mútrágyázás. A terméstöbbletek elérésében a három tápelem közül a N-adagnak van meghatározó szerepe. Azonban a talaj tulajdonságain, a hibrid intenzitásán kívül a klimatikus tényezôk határozzák meg a N érvényesülését (Pepó 2004, Berzsenyi és Lap 2003). Fontos a termesztett hibridek igényének megfeleló mútrágyaadag megállapítása, mert különben a kukoricahibridek genetikai potenciálja nem érvényesül (Nagy 1984, Nagy és Bodnár 1986).

Törekedni kell arra, hogy az alkalmazott mútrágyaadagok biológiai értékesülésében javulás következzen be. A kukoricahibrideknek nemcsak a termôképességük, hanem a tápanyaghasznosító képességük is nagymértékben eltérô (Sárvári 1984, Debreczeniné 1985).

Az utóbbi időben a célszerú nemesítői munka eredményeként javult a hibridek természetes tápanyagfeltáró és hasznosító képessége, továbbá mútrágya-reakciójuk (Marton et al. 2005).

A P kedvezô hatása - a harmonikus tápanyag-ellátottság megteremtésén túlmenôen - többek között a tenyészidôszak lerövidülésével, korábbi éréssel magyarázható (Kádár et al. 1984).

A kukorica a P-nál jobban reagál a K-mútrágyázásra (Árendás et al. 1998). A kukoricatermesztésben ezért kiemelkedô jelentôsége van az okszerú vetésváltásnak és a harmonikus NPK tápanyag-visszapótlásnak (Nagy és Huzsvai 2005).

\section{Anyag és módszer}

A kísérletet réti talajon állítottuk be. Területének szintje a környezethez képest kiemelkedik. A szervesanyag tartalom szelvényen belüli eloszlása a mélység függvényében erôs csökkenést mutat. A felszíni 4-5\%-os érték, a 40-60 cm-es mélységben már csak 1,5\% körüli. A nagy humusztartalom eredményeként jó 
a N feltáródása. A talaj egyes tulajdonságaiban (pl. könnyebben felmelegszik, jobb a tápanyagdinamizmusa) a csernozjom réti talajhoz hasonló. Arany-féle kötöttsége 52, azonban főbb jellemző tulajdonságai (pl. az altalajvíz közelsége, a jelentôs vaskiválás) alapján a típusos réti talajok csoportjába sorolható. A hajdúböszörményi OTK kísérlet talajának múvelt rétege nedvesen iszaposodásra, kiszáradva erósen repedezésre hajlamos.

A tartamkísérletek eredményeit 1968-2004 közötti időre vonatkozóan értékeljük. A vetésváltás és a mútrágyázás termésre gyakorolt hatását a termésstabilitás mértékét 1973-1994, míg a kukoricahibridek mútrágya-reakcióját az 1980-2008 közötti idôszakban vizsgáltuk.

A csapadék 30 éves átlaga 565,3 mm. A kukorica vegetációs időszakában (IV-IX. hó) a 30 éves csapadékátlag 345,1 mm. A vizsgált időszakban a sokévi átlaghoz viszonyított csapadék mennyisége (mm) pl. 1971, 1972, 1976, 1992, 1993, 1994, 2000, 2007 években volt lényegesen kevesebb. Átlag feletti mennyiségú csapadékot, pl. 1974, 1980, 1998, 1999, 2004, 2005-ös években tapasztalhattunk (1. ábra).

\section{1. ábra. A kritikus és a vegetációs időszak csapadékadatai}

(Hajdúböszörmény, 1968-2009)

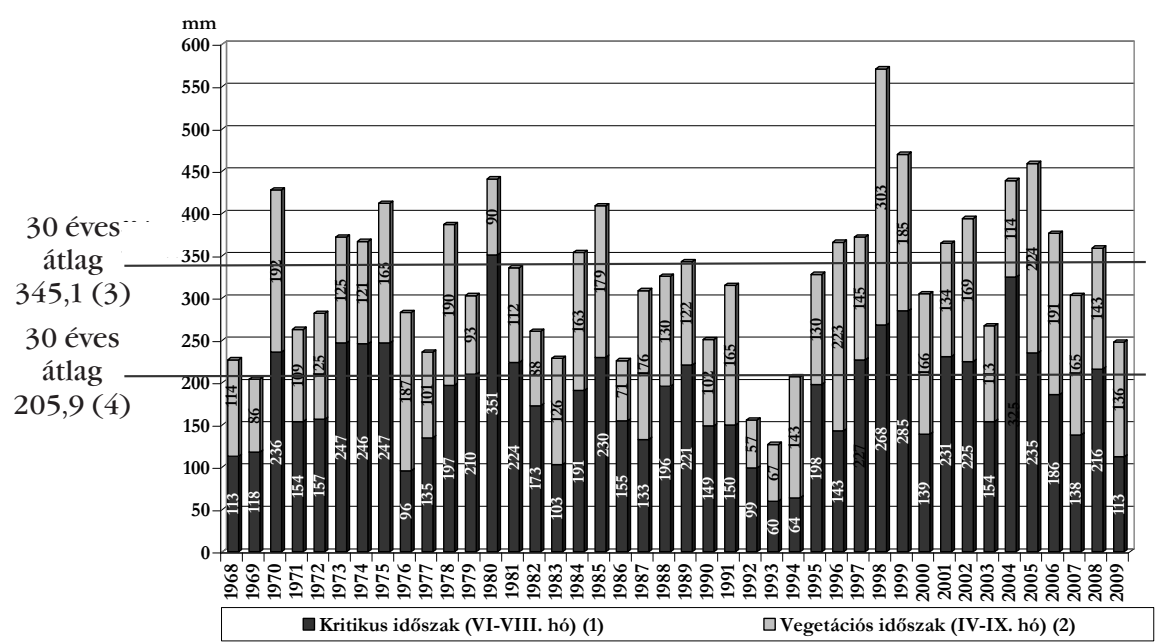

Figure 1. Rainfall data of the critical and the vegetation period (Hajdúböszörmény, 1968-2009). (1) Critical period (months VI-VIII), (2) Vegetation period (months IV-IX), (3) 30 years average (345.1), (4) 30 years average (205.9). 
Debrecen térségében az évi középhômérséklet 30 éves átlaga 9,84 ${ }^{\circ} \mathrm{C}$, a kukorica tenyészidejében $16,64^{\circ} \mathrm{C}$. A vizsgált időszakban a kukorica tenyészidejében a hômérséklet a sokévi átlagtól lényegesen alacsonyabb volt 1974-1980, illetve 1984-1991 évek között, míg 1992-2008 között lényegesen meghaladta a sokévi átlagot (2. ábra).

\section{2. ábra. Hômérséklet adatok $\left({ }^{\circ} \mathrm{C}\right)$}

(Debrecen 1968-2009)

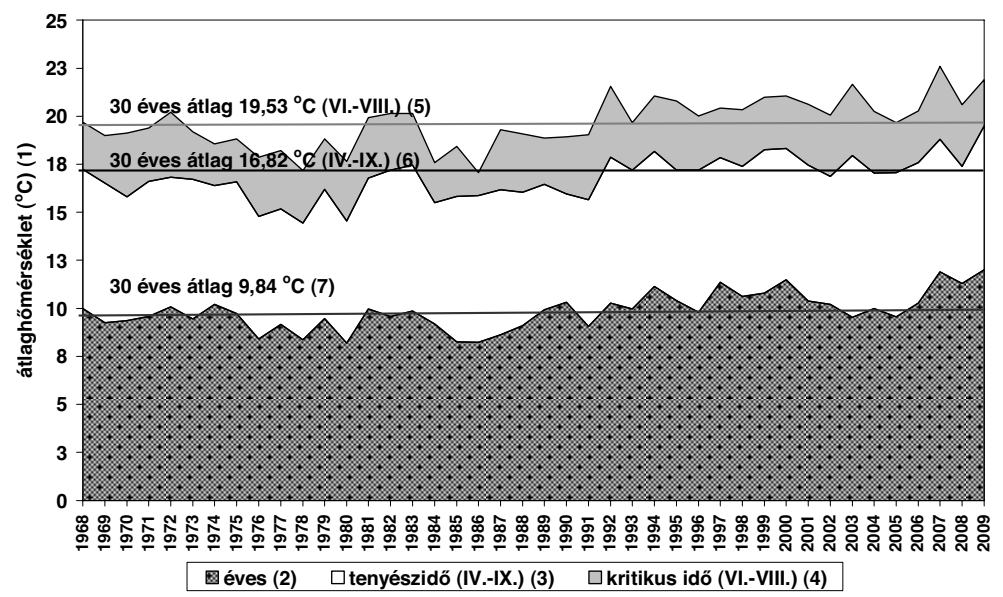

Figure 2. Temperature data $\left({ }^{\circ} \mathrm{C}\right)$ (Debrecen 1968-2009). (1) Average temperature $\left({ }^{\circ} \mathrm{C}\right),(2)$ Annual data, (3) Growing season (months IV-IX), (4) Critical period (months VI-VIII), (5) 30 years average $\left(19.53^{\circ} \mathrm{C}\right),(6) 30$ years average $\left(16.82^{\circ} \mathrm{C}\right),(7) 30$ years average $\left(9.84^{\circ} \mathrm{C}\right)$.

A vetésváltás:

- $\quad$ Trikultúra: borsó - ószi búza - kukorica - kukorica

- Bikultúra: ôszi búza - kukorica - kukorica - ószi búza

- Monokultúrás kukorica

Az NPK mútrágyaadagok a kontroll (mútrágyázás nélküli) kezelés mellett az alábbiak voltak (kg/ha hatóanyagban):

$\begin{array}{crcr}\text { A kísérlet évei } & 1-4 . \text { éve } & 5-20 . \text { éve } & 21 . \text { évtôl } \\ \mathrm{N} & 40-160 & 50-250 & 50-250 \\ \mathrm{P}_{2} \mathrm{O}_{5} & 35-105 & 50-150 & 60-180 \\ \mathrm{~K}_{2} \mathrm{O} & 100 & 100 & 100-250\end{array}$


A különböző kukoricahibridek NPK mútrágya-reakciójának tesztelésénél a kontroll mellett $\mathrm{N} 40-200, \mathrm{P}_{2} \mathrm{O}_{5} 25-125, \mathrm{~K}_{2} \mathrm{O} 30-150 \mathrm{~kg} /$ ha hatóanyagot juttatunk ki.

A kukorica talajelôkészítésénél 30-35 cm-es szántást végeztünk. A vegyszeres gyomirtást az adott idôszakban az üzemi körülmények között alkalmazott módon végeztük. A betakarítás parcella betakarító kiskombájnnal (néhány esetben kézzel) történt. A termést minden esetben 86\%-os szárazanyag-tartalomra számítottuk át.

A kísérleti eredmények kiértékelését kéttényezős varianciaanalízissel, parabolikus regressziós analízissel, főkomponens analízissel és stabilitás analízissel végeztük.

\section{Eredmények}

A vetésforgó és a mütrágyázás hatása a kukorica termésére és termésstabilitására

A vetésváltás a kukorica termése mellett a mútrágya agroökológiai optimumát is nagymértékben meghatározta. A mútrágyázott parcellákon trikultúrában (borsó - ôszi búza - kukorica - kukorica) 1973-tól 1994-ig vizsgálva 1,58 t/ha-ral nagyobb termést értünk el a monokultúrás termesztéshez viszonyítva. Trikultúrában még a bikultúrához (ôszi búza - kukorica - kukorica - ôszi búza) viszonyítva is 1,25 t/ha-ral nagyobb termést kaptunk (3. ábra, 2. táblázat).

A három vetésforgó termésadatai között mútrágyázás nélkül jelentôs különbségek voltak. Trikultúrában a kontroll (mûtrágyázás nélküli) kezelésnél több év átlagában a termés 7,66 t/ha, bikultúrában 7,88 t/ha, míg monokultúrában csak 5,73 t/ha volt. A vizsgált hibridek 1973-1980 között Mv SC 580-as, 1981-1983 között Sze SC 444-es és 1984-1994 között a Pioneer SC 3732-es voltak.

A vetésforgó a kukorica termésstabilitását (1973-1987) is nagymértékben meghatározta.

A termést - mint a vizsgálati eredményekből láthatjuk - legnagyobb mértékben (26\%-ban) a csapadék mennyisége határozta meg. Különösen fontos a kukorica tenyészidején belül a kritikus idôszak (VI-VIII. hó) csapadékellátottsága.

A vetésforgó hatása a kukorica termésstabilitására a 4. ábrán is látható.

Kedvezótlen környezeti feltételek mellett, trikultúrában a legstabilabb a kukorica termése. Ugyanakkor a környezeti feltételek javulásával szintén a trikultúrás kukorica képes a legnagyobb (akár 18 t/ha feletti) terméseredményre. 


\section{3. ábra. Mútrágyázás és a vetésforgó hatása a kukorica termésére} (Országos Mútrágyázási Tartamkísérlet, Hajdúböszörmény, 1973-1994)
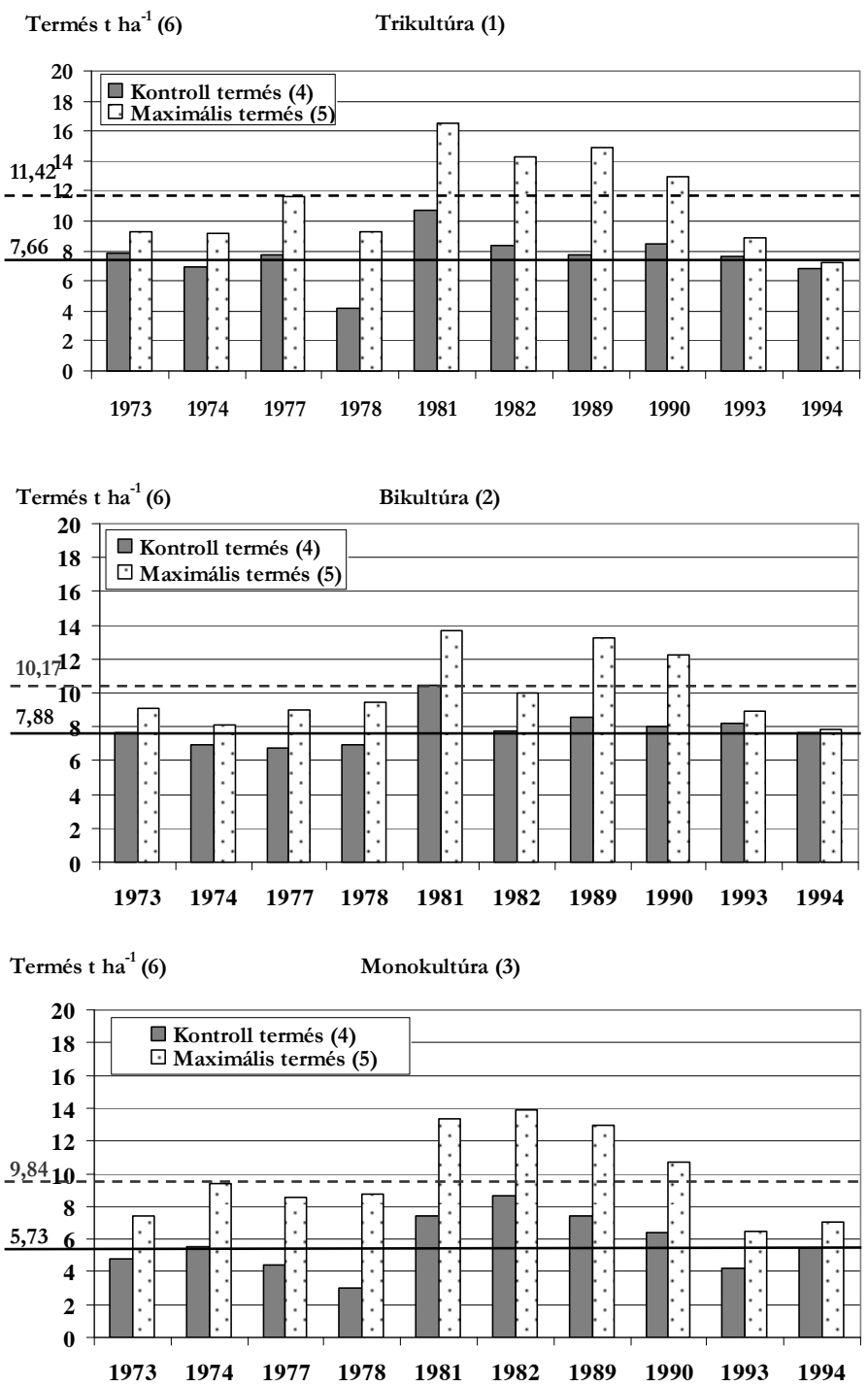

Figure 3. The effect of fertilisation and crop rotation on maize yield (National Fertilisation Long-term Experiment, Hajdúböszörmény, 1973-1994). (1) Triculture, (2) Biculture, (3) Monoculture, (4) Control yield, (5) Maximum yield, (6) Yield $\mathrm{t} \mathrm{ha}^{-1}$. 
2. táblázat. A 3. ábra varianciaadatai

\begin{tabular}{lccccc}
\hline \multicolumn{1}{c}{$\begin{array}{c}\text { Évek } \\
(1)\end{array}$} & 1973 & 1974 & 1977 & 1978 & 1981 \\
\hline SzD5\%vetésforgó (2) & 0,57 & 0,44 & 0,21 & 0,32 & 0,52 \\
Mútrágyázás (3) & 0,53 & 0,44 & 0,39 & 0,58 & 0,84 \\
Kölcsönhatás (4) & 0,91 & 0,70 & 0,68 & 1,01 & 1,45 \\
\hline \multicolumn{1}{c}{ Évek } & 1982 & 1989 & 1990 & 1993 & 1994 \\
\multicolumn{1}{c}{$(1)$} & 0,67 & 0,76 & 1,52 & 0,74 & 1,01 \\
\hline SzD5\% vetésforgó (2) & 0,66 & 0,96 & 1,09 & 0,66 & 0,52 \\
Mútrágyázás (3) & 1,15 & 1,66 & 1,88 & 1,15 & 0,90 \\
Kölcsönhatás (4) & & & & & \\
\hline
\end{tabular}

Table 2. Variance data of the $3^{\text {th }}$ figure's. (1) Years, (2) $\mathrm{LSD}_{5 \%}$ crop rotation, (3) Fertilisation, (4) Interaction.

4. ábra. A vetésforgó hatása a kukorica termésstabilitására (1973-1987)

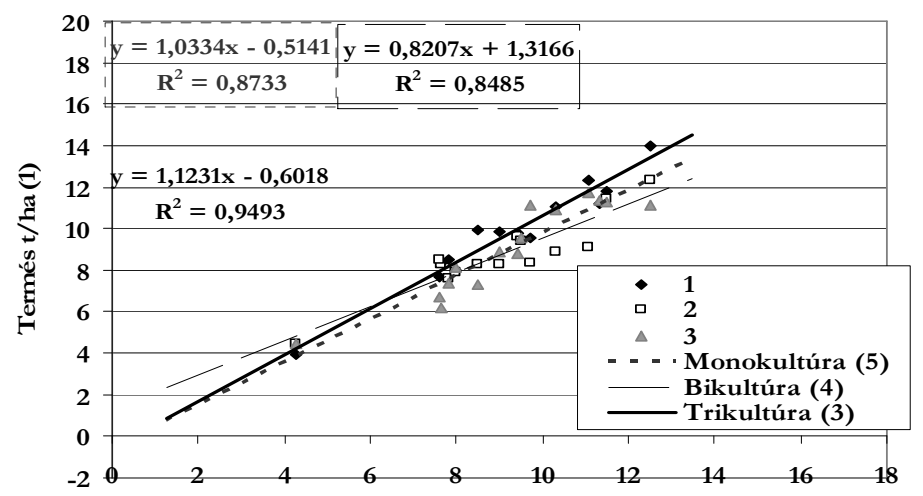

Környezet átlaga t/ha (2)

Figure 4. The effect of crop rotation on the yield stability of maize (1973-1987). (1) Yield t ha ${ }^{-1}$, (2) Average of the environment t ha' ${ }^{-1}$, (3) Triculture, (4) Biculture, (5) Monoculture.

A vetésforgó és az NPK mútrágyázás együttes hatása a kukorica termésstabilitására nagymértékben eltér trikultúrában és monokultúrában (5. ábra).

Megállapítható, hogy trikultúrában, harmonikus NPK mútrágyázás mellett lényegesen több termést lehet elérni a monokultúrás termesztéshez viszonyítva.

A mútrágyázás nélküli kezelésnél a legstabilabb, de egyben a legkisebb a termés. 
A vetésforgó és a N-mútrágyázás jelentős mértékben befolyásolta a talaj pH értékét és a $\mathrm{NO}_{3}-\mathrm{N}$ tartalmát. Lényegesen módosította a $\mathrm{NO}_{3}-\mathrm{N}$ talajszelvényben való felhalmozódását.

5. ábra. A trikultúrás és monokultúrás termesztés valamint az NPK mútrágyázás hatása a kukorica termésstabilitására (1973-1987)
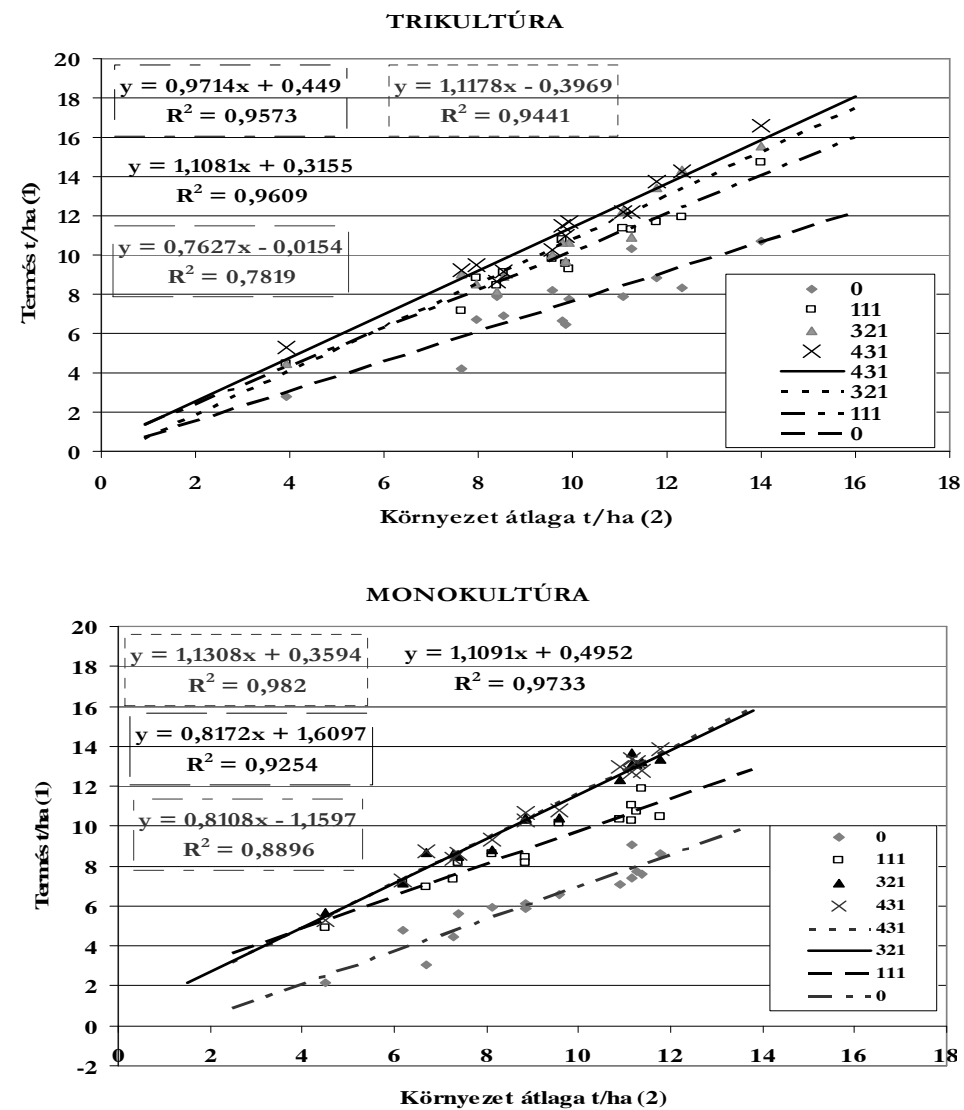

Múttrágyakezelés jelölése: $0=$ kontroll, $1 \mathrm{~N}=50 \mathrm{~kg} / \mathrm{ha}, 1 \mathrm{P}_{2} \mathrm{O}_{5}=50 \mathrm{~kg} / \mathrm{ha}, 1 \mathrm{~K}_{2} \mathrm{O}=100 \mathrm{~kg} / \mathrm{ha}$. A 2-es, 3-as, 4-es jelölés a mútrágya alapadag 2×-es, 3×-os, 4×-es adagját jelenti. Az 1. helyi érték a N-t, a 2-es a $\mathrm{P}_{2} \mathrm{O}_{5}$-t, a 3-as a $\mathrm{K}_{2} \mathrm{O}$ hatóanyagot jelöli.

Figure 5. The effect of triculture and monoculture production, as well as NPK fertilisationon the yield stability of maize (1973-1987). (1) Yield $t \mathrm{ha}^{-1}$, (2) Average of the environment t ha' ${ }^{-1}$

Indication of the fertiliser treatment: $0=$ control, $1 \mathrm{~N}=50 \mathrm{~kg} \mathrm{ha}^{-1}, 1 \mathrm{P}_{2} \mathrm{O}_{5}=50 \mathrm{~kg} \mathrm{ha}^{-1}, 1 \mathrm{~K}_{2} \mathrm{O}=100 \mathrm{~kg} \mathrm{ha}^{-1}$. Indications 2, 3 and 4 represent doses 2, 3 and 4 times higher than the basic dose. Digit one represents $\mathrm{N}$, two represents $\mathrm{P}_{2} \mathrm{O}_{5}$ and 3 represents $\mathrm{K}_{2} \mathrm{O}$. 
A kukorica talajának pH értéke KCl-ban mérve monokultúrában szignifikánsan alacsonyabb a másik két vetésforgó talajának pH értékéhez viszonyítva $(5,74)$ (3. táblázat).

3. táblázat. A tri-, bi-és monokultúra talajának átlagos pH $(\mathrm{KCl})$ értékei

\begin{tabular}{lcccc}
\hline & $\begin{array}{c}16 . \text { év } \\
\end{array}$ & $\begin{array}{c}20 . \text { év } \\
(1)\end{array}$ & $\begin{array}{c}24 . \text { év } \\
(2)\end{array}$ & $\begin{array}{c}28 . \text { év } \\
(4)\end{array}$ \\
\hline Trikultúra (5) & 5,8808 & 6,1333 & 6,3186 & 6,4859 \\
Bikultúra (6) & 6,0023 & 6,1918 & 6,3744 & 6,3924 \\
Monokultúra (7) & 5,7395 & 5,8264 & 5,6166 & - \\
SzD5\%(8) & 0,2358 & 0,2605 & 0,2229 & 0,1216 \\
\hline
\end{tabular}

Table 3. Average soil $\mathrm{pH}(\mathrm{KCl})$ values of the tri-, bi- and monoculture. (1) $16^{\text {th }}$ year, (2) $20^{\text {th }}$ year, (3) $24^{\text {th }}$ year, (4) $28^{\text {th }}$ year, (5) Triculture, (6) Biculture, (7) Monoculture, (8) $\mathrm{LSD}_{5 \%}$.

Az eredmény magyarázata az lehet, hogy monokultúrás termesztésnél aszályos években a nagyobb adagú N-trágyázást nem követte megfelelő termésnövekedés. A $\mathrm{N}$ így nagyobb mértékben csökkentheti a talaj $\mathrm{pH}$ értékét. $\mathrm{A} \mathrm{NO}_{3}-\mathrm{N}$ bemosódása az altalajvízbe szintén a monokultúrás termesztésnél volt a legnagyobb.

A kísérlet 26. évére a búza elővetemény utáni kukorica talajában a 100-120 cm-es talajszelvényben a $\mathrm{NO}_{3}-\mathrm{N} 50 \mathrm{mg} / \mathrm{kg}$ alatt maradt, míg monokultúrás termesztésnél a $175 \mathrm{mg} / \mathrm{kg}$-ot is elérte, ami a N jelentős hatékonyság csökkenése mellett nagymértékú környezetszennyezést is jelentett.

A fenti eredmények megfelelően bizonyítják az okszerú vetésváltás jelentôségét. Trikultúrában a borsó kedvezô elővetemény-hatását még a 2-3. évben is mérni lehetett az utána következő növények terméstöbbletében.

A vetésváltás jelentôsége a jövőben a klímaváltozással összefüggésben még jobban fel fog értékelődni.

\section{Kukoricahibridek mütrágyareakciója tartamkísérletben}

A kukoricahibridek termőképessége, természetes tápanyagfeltáró és hasznosító képessége, továbbá trágyareakciója is nagymértékben eltérô. Egyre korszerúbb kukoricahibridek, biológiai alapok kerülnek a termesztésbe, melyeknek nemcsak a termôképességük nagyobb, hanem a mútrágya-hasznosító képességük is egyre jobb. Míg az 1970-80-as években $180 \mathrm{~kg} / \mathrm{ha} \mathrm{N}$ jelentette az agroökológiai optimumot, addig napjainkban ez $120 \mathrm{~kg} / \mathrm{ha} \mathrm{N}$ hatóanyag. A jobb 
mútrágyareakcióval rendelkezó hibrideknek valószínúleg kedvezóbb a NRA (Nitrát-Reduktáz-Enzim) kapacitása, nagyobb a gyökértömegen belül a gyökérszőrök adszorpciós kapacitása.

Az 1980 és a 1997. évi vizsgálati eredményeknél (6. ábra) látható, hogy a Pioneer 3901-es hibrid már mútrágyázás nélkül is 7,5 t/ha körüli terméseredményt ért el. A mútrágyázás a termését jelentôsen tovább növelte. Míg a JX 62-es hibrid termése mútrágyázás nélkül csak 4 t/ha és a mútrágya-reakciója sem kedvezô. Látható ugyanakkor, hogy a Clarisia és az Evelina termése között mútrágyázás nélkül is közel 2 t/ha az eltérés.

6. ábra. A kukoricahibridek termőképessége és mütrágyareakciója réti talajon (1980, 1997)
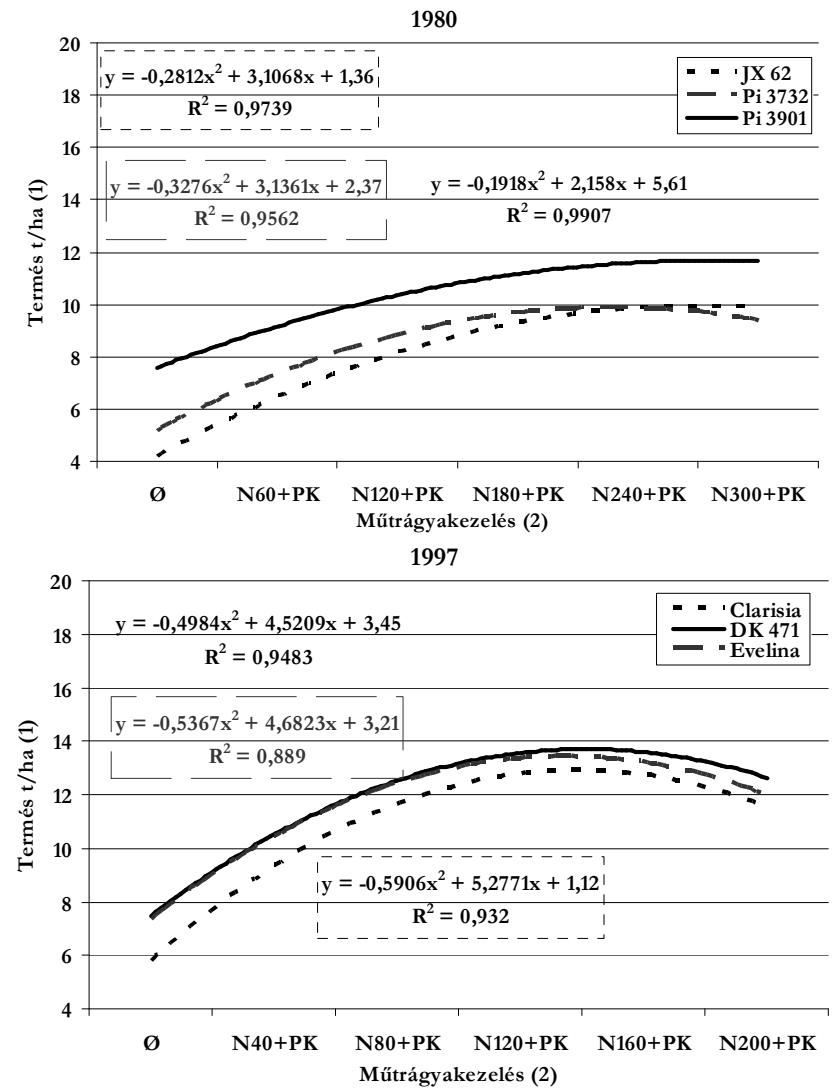

Figure 6. Yield potential and fertiliser reaction of maize hybrids on meadow soil $(1980,1997)$. (1) Yield t ha ${ }^{-1}$, (2) Fertiliser treatment. 
A mútrágyázás termésnövelő hatása látható a 7. ábrán. Megállapítható, hogy a mútrágyázás nélküli kezelésekhez viszonyítva a legnagyobb termésnövekedést (2-3 t/ha-t) a viszonylag kis, de harmonikus $\mathrm{N} 40, \mathrm{P}_{2} \mathrm{O}_{5} 25, \mathrm{~K}_{2} \mathrm{O} 30$ $\mathrm{kg} /$ ha-os kezelés eredményezte. Ezt a mútrágyaadagot megduplázva, a termés már csak 0,5-1,0 t/ha-ral nőtt.

\section{7. ábra. A mútrágyázás hatása a kukoricahibridek termésére (2007-2008)}
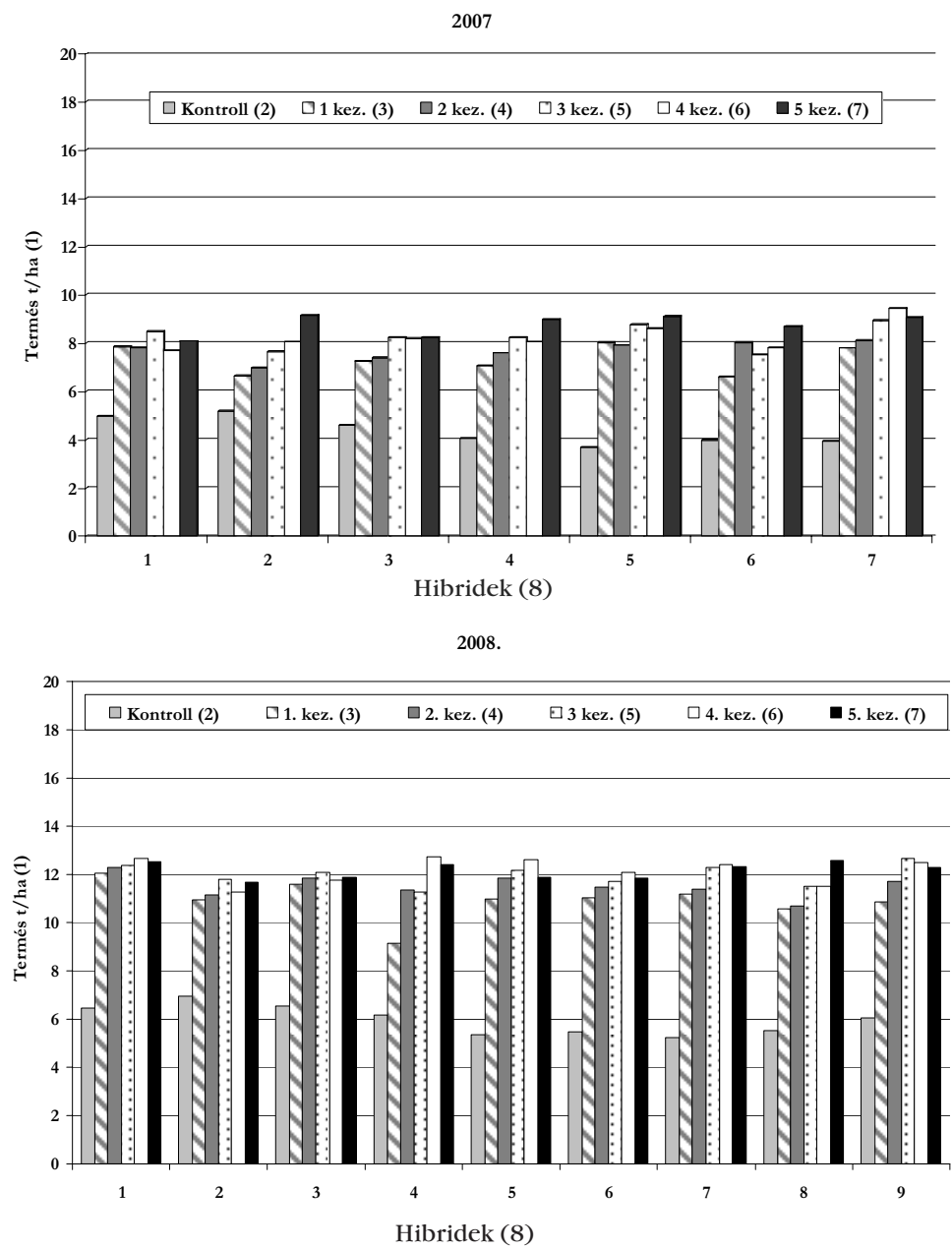

Figure 7. The effect of fertilisation on the yield of maize hybrids (2007-2008). (1) Yield $t \mathrm{ha}^{-1}$, (2) Control, (3) Treatment 1, (4) Treatment 2, (5) Treatment 3, (6) Treatment 4, (7) Treatment 5, (8) Hybrids. 
Több év átlagában előveteménytől, évjárattól és a hibridtől függően az agroökológiai NPK mútrágyaoptimum - az az optimum, amellyel a legnagyobb termést el lehet érni - N 40-120, $\mathrm{P}_{2} \mathrm{O}_{5} 25-75, \mathrm{~K}_{2} \mathrm{O} 30-90 \mathrm{~kg} / \mathrm{ha}$ hatóanyag volt. A hosszabb tenyészidejû hibridek nagyobb termőképességéhez nagyobb tápanyagigény társul. A jelölt mútrágya hatóanyagok dózisát a 8. ábrán ismertetjük.

8. ábra. A hibridek csoportositása termóképesség és mútrágyareakció alapján

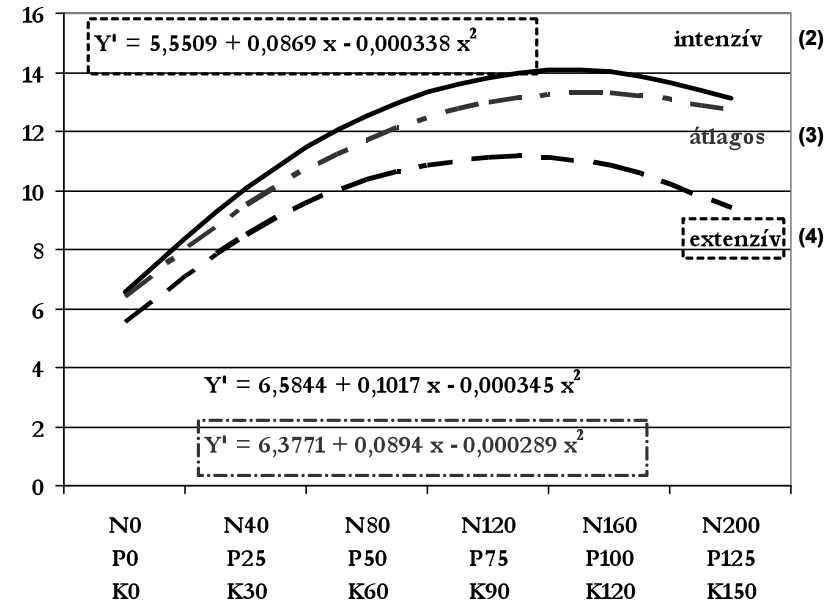

Figure 8. Classification of hybrids based on yield potential and fertiliser reaction. (1) Yield $\mathrm{t} \mathrm{ha}^{-1}$, (2) Intensive, (3) Average, (4) Extensive.

Az évjárat hatása aszályos évben képes a mútrágyázás hatását elfedni. 2007ben a hibridek termése még megfelelố tápanyagellátás mellett is csak 8-9 t/ha volt, míg a kedvezó 2008. évben 12-13 t/ha-t is elérte.

A kukoricahibrideket a termőképesség és a mútrágya-reakció alapján intenzív, átlagos és extenzív csoportokba sorolhatjuk (8. ábra). E csoportosítás a hibridek termôhelyre való ajánlásánál jelent fontos információt. Az extenzív hibrideket a kevésbé jó termóhelyre, az intenzíveket az átlagosnál jobb termőhelyre ajánljuk. Megfordítva kettős hátrány jelentkezhet.

- Extenzív hibriddel nem tudjuk az átlagosnál jobb termóhelyeket kihasználni.

- A kevésbé jó termőhelyen az intenzív hibrid termóképessége nem érvényesülhet. 


\section{IRODALOM}

Árendás T.-Sarkadi J.-Molnár D.: 1998. Mútrágyahatások kukorica-ôszi búza dikultúrában erdőmaradványos csernozjom talajon. Növénytermelés. 47. 1: 45-57.

Berzsenyi Z.: 1995. A kukoricatermesztési technológiák fenntarthatóságának vizsgálata stabilitásanalízissel tartamkísérletekben. A fenntartható fejlôdés idôszerú kérdései a mezôgazdaságban. 37. Georgikon Napok. Keszthely. 27-36.

Berzsenyi Z.-Lap D. Q.: 2003. A N-mútrágyázás hatása a kukorica (Zea mays L.) hibridek szemtermésére és N-mútrágyareakciójára tartamkísérletben. Növénytermelés. 52. 3-4: 389-408.

Debreczeni B.-né: 1985. A kukorica ásványi táplálkozása. [In: Menyhért Z. (szerk.) A kukoricatermesztés kézikönyve.] Mezógazdasági Kiadó. Budapest.

Kádár I.-Csathó P.-Sarkadi J.: 1984. A szuperfoszfát tartamhatásának vizsgálata ôszi búza monokultúrában. I. Talajvizsgálati és szemterméseredmények. Agrokémia és Talajtan. 33. 375-390.

Kismányoki T.: 1994. Vetésváltás, vetésforgó, monokultúra. [In: Ragasits I. (szerk.) Növénytermesztés.] Mezőgazda Kiadó. Budapest. 48-52.

Kiss I.-né: 2000. A kukorica termesztéstechnológiájának áttekintése. Gyakorlati Agrofórum. 11. 3: 2-9.

Marton L. Cs.-Szundy T.-Hadi G.-Pintér J.-Berzsenyi Z.-Árendás T.-Bónis P.: 2005. A termelői igényekhez igazodó kukoricanemesítés szempontjai Martonvásáron. Gyakorlati Agrofórum Extra. 9: 11-13.

Menyhért Z.-Ángyán J.-Radics L.: 1980. Vetésváltás vagy monokultúra? Magyar Mezőgazdaság. 35: 52-53.

Nagy J.: 1984. Mútrágyázás hatása a kukoricahibridek termésére mészlepedékes csernozjom talajon. Növénytermelés. 33. 3: 253-264.

Nagy J.-Bodnár E.: 1986. Az öntözés, a mútrágyázás és a tôszám hatása a kukoricahibridek termésére. Növénytermelés. 35. 6: 535-546.

Nagy J.-Huzsvai L.: 2005. Hibridválasztás a kukoricatermesztés középpontjában. Gyakorlati Agrofórum Extra. 9: 30-32.

Pepó P.: 2004. Ốszi búza tápanyagellátása a Hajdúságban. MTA Doktori Értekezés. Debrecen.

Sárvári M.: 1984. Különböző kukoricahibridek tápanyag-reakciója réti talajon. Növénytermelés. 33. 6: 549-558.

Sárvári M.: 2004. Új módszerek és eljárások a kukoricatermesztésben. Agro Napló. Országos Mezógazdasági Szaklap. 8. 4: 13-15.

Széll E.-Makhajda J.: 2003. Kukoricatermesztés monokultúrában vagy vetésváltással? http://www.agrarkamara.bekescsaba.hu/gtars/viii4/1819.html 2005. 07. 12. 
A szerzók levelezési címe - Address of the authors:

Dr. Sárvári Mihály-Boros Beáta

Debreceni Egyetem AGTC

Növénytudományi Intézet

Debrecen

Böszörményi út 138.

H-4032 